\title{
Khellin: A furanochromone with toxicity against Oncopeltus fasciatus (Hemiptera) and Aedes aegypti (Diptera)
}

ARTICLE $\cdot$ JANUARY 2013

DOI: 10.4103/2229-5119.110348

CITATION

1

7 AUTHORS, INCLUDING:

Marise Maleck

Universidade Severino Sombra

37 PUBLICATIONS 277 CITATIONS

SEE PROFILE
READS

23 


\title{
Khellin: A furanochromone with toxicity against Oncopeltus fasciatus (Hemiptera) and Aedes aegypti (Diptera)
}

\author{
Marise Maleck ${ }^{1,2,6}$, Fernanda Cristina Carvalho dos Santos ${ }^{1}$, Michele Teixeira Serdeiro, ${ }^{1,6}$, \\ Anthony Érico Guimarães², Bruna Ferreira ${ }^{1,2}$, Keriman Gunaydin ${ }^{3}$, Ana Paula de Almeida ${ }^{4,5,6}$
}

\section{ABSTRACT}

Natural products isolated from plants may be an alternative source of larvicidal and insecticide activity. Khellin is a natural furanochromone isolated from fruits of Ammi visnaga (L.) Lam. (Umbelliferae family), which grows extensively in the Mediterranean region. This substance shows several types of biological activity, such as in vitro cytotoxicity, antispasmodic action, and phototherapeutic potential. Dengue is a tropical disease caused by an arbovirus transmitted by Aedes aegypti; the milkweed bug, Oncopeltus fasciatus, is a phytophagous Hemiptera and a Phytomonas vector. Our main goal was to evaluate the toxicity of khellin in relation to the nymphs of $O$. fasciatus (Hemiptera) and larvae of $A$. aegypti (Diptera). To the best of our knowledge, this is the first report concerning furanochromone bioactivity against insect vectors for human disease.

Keywords: Ammi visnaga (L.), bioactivity, culicidae, hemiptera, larvicidal, natural products

Access this article online

Website: www.jnatpharm.org DOl: 10.4103/2229-5119.110348

Quick Response Code:

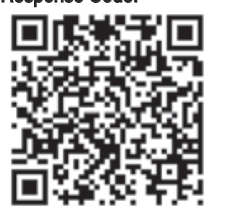

Address for correspondence: Dr. Maleck, M., Laboratório de Insetos Vetores/CECETEN and Mestrado Profissional em Ciências Ambientais, Universidade Severino Sombra, Rua Expedicionário Oswaldo Almeida Ramos, $n^{\circ} 280$

- Centro, Vassouras, RJ, Brazil.

E-mail: mmaleck@ oi.com.br

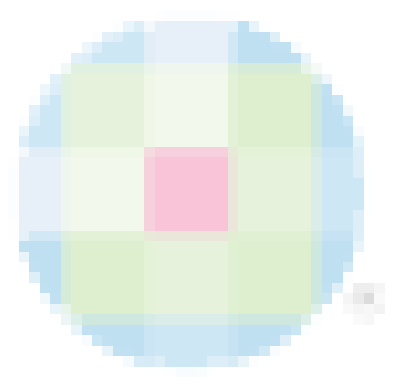

\section{INTRODUCTION}

Plants are a rich source of pharmacologically active substances and some of them show larvicidal and insecticide activity ${ }^{[1,2]}$ with regard to controlling undesirable insects in agricultural crops ${ }^{[3]}$ homes, and gardens that have public health implications. ${ }^{[4,5]}$ Khellin [Figure 1] is a furanochromone isolated from Ammi visnaga (Lam.) Lamarck, a plant in the Umbelliferae (Apiaceae) family that grows extensively in the Mediterranean region. In Europe, the plant has often been referred to as the toothpick herb or bishop's weed, while in Turkey it is known as "disotu", "kilir," and "hiltan". ${ }^{[6]}$

A. visnaga has been used as a diuretic and to treat urinary tract pain caused by urethral stones. Pharmacological studies have confirmed that furanochromone derivatives, especially khellin, visnagin, and pyranocoumarin fractions, are responsible for the antispasmodic action of this plant. ${ }^{[6]}$ A butanolic extract of $A$. visnaga has demonstrated antioxidant activity, while the essential oil has exhibited antibacterial activity. ${ }^{[7,8]}$ Studies using khellin have shown several types of biological activity, such as in vitro cytotoxicity ${ }^{[9]}$ and bioactivity for vitiligo treatment. ${ }^{[10,11]}$

Dengue is an epidemic and neglected disease that accounts annually for several million cases and deaths worldwide. ${ }^{[12]}$ Dengue fever is transmitted by the mosquito Aedes aegypti Linnaeus, 1762 (Diptera: Culicidae), and is one of the most rapidly spreading insectborne diseases. Worldwide, more than 2.5 billion people are at risk of infection by the dengue vector, $A$. aegypti. ${ }^{[12]}$ In Brazil, up to October 2010, 936,260 cases had been notified, with 592 dengue-related deaths. ${ }^{[12]}$

A. aegypti is a cosmopolitan mosquito that can be found in tropical and subtropical 


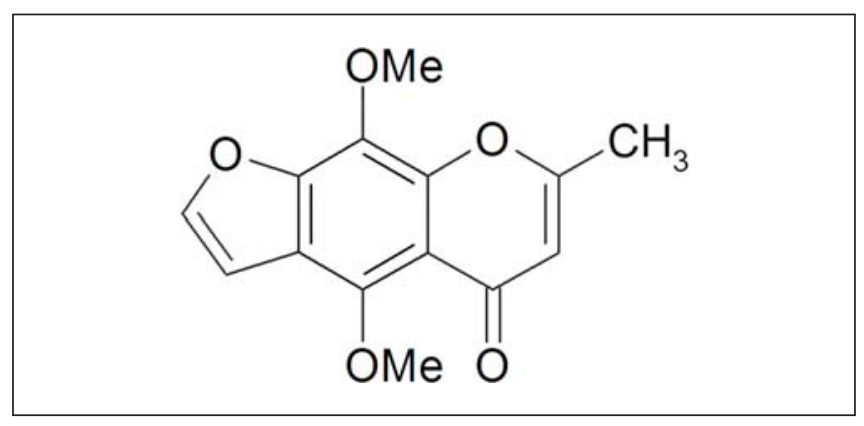

Figure 1: Chemical Structure of khellin (4, 9-dimethoxy-7-methylfuro[3, 2-g] chromen-5-one)

regions. ${ }^{[13,14]}$ Several viral serotypes produce human infection. ${ }^{[15]}$ Studies have revealed that $A$. aegypti larvae present widespread resistance to the organophosphate temephos throughout Brazil. ${ }^{[16]}$ Resistance of adult A. aegypti to the currently used pyrethroids such as cypermethrin and deltamethrin has also been reported. ${ }^{[17]}$ In view of this information and the fact that development of a multi-serotype vaccine is still a distant goal, ${ }^{[12]}$ the only means of reducing infection rates is to control the insect vector. Therefore, new approaches are urgently needed.

The milkweed bug, Oncopeltus fasciatus Dallas, 1852 (Hemiptera: Lygaidae), occurs over a wide geographical range extending from Massachusetts westwards over the greater part of the United States and southwards to Mexico and Brazil. ${ }^{[18]}$ This Hemiptera is a phytophagous insect usually found on Asclepias curassavica (popular name "oficial de sala") and is a Phytomonas vector. ${ }^{[18,19]}$ It provides a convenient model for testing the effects of substances on development and mortality. ${ }^{[19]}$ Milkweed bugs can be cultivated in dry sunflower seeds (Helianthus annuus), present a short cycle, require little space, and are large enough to be easily observed. ${ }^{[20]}$ In their natural environment, they feed on the seeds of milkweed plants by piercing the seed pod. They also will feed on nectar and on the plant's juices. Since they are not a much of pollinator, they have been considered to be pests that pierce leaves and facilitate pathogen penetration. ${ }^{[21]}$ The present study evaluated the toxicity of khellin on nymphs of the Hemiptera $O$. fasciatus and larvae of the Diptera A. aegypti.

\section{MATERIALS AND METHODS}

\section{General Experimental}

${ }^{1} \mathrm{H}$ and ${ }^{13} \mathrm{C}$ NMR spectra were recorded in $\mathrm{CDCl}_{3}$ and DMSO/benzene with TMS as internal standard on a Bruker AC $200 \mathrm{~L}$ instrument operating in 200 and $50.32 \mathrm{MHz}$, respectively. UV sprectra was recorded in a Shimadzu UV-1208 UV-Vis Spectrophotometer using $\mathrm{CHCl}_{3}$. Si gel for column chromatography were silica gel
60 (0.2-0.5 mm) (Macherey -Nagel). Solvents used were from Merck and Pronalab with "pró-analysis" and "pure" degree of purity.

\section{Plant Material}

The plant material was collected near Hatay, Turkey, and was identified by the botanist Vagif Hatemov, at Mustafa Kemal University, Hatay. A voucher specimen has been deposited in the Herbarium of the Biology Department, Mustafa Kemal University.

\section{Extraction and Isolation}

The dried, ripe fruits (100 g) were extracted with methanol (2 L) in a Soxhlet extractor for $30 \mathrm{~h}$. The solvent was evaporated and the residue ( $8 \mathrm{~g})$ was dissolved in EtOHwater. This solution was extracted with hexane (5'200 mL) and chloroform (5'200 mL). The chloroform extract (1,2 g) was subject to column chromatography over Si gel (0.2-0.5 mm Merck; $100 \mathrm{~g}$ ) and eluented with mixture of hexane, hexane-dichloromethane, dichloromethane-acetone, $50 \mathrm{ml}$ fractions being collected as follows: fractions 1-6 (hexane), 7-17 (hexane-dichloromethane, 7:3), 18-38 (hexanedichloromethane, 5:5), 39-50 (hexane-dichloromethane, 3:7), 51-61 (dichloromethane), 62-85 (dichloromethane-acetone, 9:1), 86-100 (dichloromethane-acetone, 5:5),101-115 (dichloromethane-acetone, 3:7), 115-130 (acetone). Fractions 62-85 were combined and compound 1 (560 mg) obtained by crystallization with methanol.

Khellin (1) crystallized from $\mathrm{MeOH}$, m.p. $154-155^{\circ} \mathrm{C}, \mathrm{UV}$ max nm: 275.322. ${ }^{1} \mathrm{H}-\mathrm{NMR}\left(200 \mathrm{MHz} \mathrm{CDCl}_{3}\right)$ : $\delta$, ppm 7.65 (d, $J=2 \mathrm{~Hz}, \mathrm{H}-2) ; 7.03$ (d, J=2 Hz, H-3); 6.06 (s, H-6); 4.19 $\left(\mathrm{s}, \mathrm{OCH}_{3}\right) ; 4.06\left(\mathrm{~s}, \mathrm{OCH}_{3}\right) ; 2.4\left(\mathrm{~s}, \mathrm{CH}_{3}\right) .{ }^{13} \mathrm{C}-\mathrm{NMR}\left(\mathrm{CDCl}_{3}\right)$ : $\delta=$ ppm 178.2 (C5); 163.9 (C13); 148.8 (C11); 147.3 (C9); 147.1 (C4); 145.5 (C3); 129.9 (C10); 119.4 (C7); 113.7 (C11); 110.8 (C6); $105.2(\mathrm{C} 2) ; 62.3\left(\mathrm{C} 9-\mathrm{OCH}_{3}\right) ; 61.8$ $\left(\mathrm{C} 4-\mathrm{OCH}_{3}\right) ; 20.1\left(\mathrm{C} 7-\mathrm{CH}_{3}\right) \cdot{ }^{[6]}$

\section{Biological Assays \\ O. fasciatus (Hemiptera: Lygaidae)}

The $O$. fasciatus specimens used in this study were taken from a longstanding colony that has been reared and maintained in the Vector Insect Laboratory, Severino Sombra University, RJ. The food used was sunflower seeds; water was provided; and the insects were maintained in an incubator (BOD) at $24.5 \pm 1^{\circ} \mathrm{C}$ and $68 \pm 10 \%$ RH. ${ }^{[22]}$

Bioassays were performed in the Vector Insect Laboratory, Severino Sombra University. The treatment on $O$. fasciatus consisted of applications to groups of 20 fifth-stage nymphs in triplicate, with three replications. There were two controls: a control group without khellin or solvent and a testimony control, with the addition of chloroform and solvent dilution. The insects were previously deprived of water and food (sunflower 
seeds) for $24 \mathrm{~h}$ before treatment. Khellin was dissolved with acetone and then diluted in $0.15 \mathrm{M} \mathrm{NaCl}(1: 4)$, to concentrations of 0.5 to $300 \mathrm{mg} / \mathrm{mL}$. The treatment consisted of applications of the substance to the abdomen of the insects $(\mu \mathrm{L})$ at concentrations of 1,10 and $100 \mu \mathrm{g} /$ nymph. After the treatments, the treated insects and control groups were kept at $24.5 \pm 1^{\circ} \mathrm{C}$ and $68 \pm 10 \%$ relative humidity $(\mathrm{RH})$ with a normal diet (sunflower seeds and water) and were observed for 30 days, regarding development and mortality.

\section{A. aegypti (Diptera: Culicidae)}

A. aegypti eggs were obtained from the Vector Support and Research Venter (Núcleo de Apoio e Pesquisa de Vetores, NapVE), Instituto Oswaldo Cruz, FIOCRUZ, Rio de Janeiro. The bioassays were performed in the Diptera Laboratory, Instituto Oswaldo Cruz, FIOCRUZ. All the experiments were carried out on third-instar (L3) larvae. The treatment on A. aegypti consisted of applications of the substance at final concentrations of 10 and $50 \mu \mathrm{g} / \mathrm{mL}$, in glass containers $(4.0 \mathrm{~cm}$ diameter ' $4.5 \mathrm{~cm}$ high) containing dechlorinated water $(10 \mathrm{~mL}){ }^{[23]}$ After 1 hour of treatment, the medium was added to a diet of fish meal (Alcon Guppy) at $0.3 \mathrm{mg} / \mathrm{larvae}$, for the mosquitoes to develop. ${ }^{[24]}$ Ten third-stage (L3) larvae were used per group: test, control (without khellin or solvent), and testimony control (solvent containing the dilution of the substance). Larval viability, pupae, emergence, and mortality of immature stages were evaluated. In both treatments, the experiments were performed in triplicate with three replicates. After treatment, the insects were kept on a normal diet in climate-controlled chambers (BOD) at $27 \pm 1^{\circ} \mathrm{C}$ and $70 \pm 10 \% \mathrm{RH}$, with $12 \mathrm{~h}$ photoperiods, and were observed for 35 days with regards to development and mortality.

\section{Statistical Analyses}

The results were analyzed using the Tukey test with a significance level of $5 \%$, analysis of variance (ANOVA) ${ }^{[25]}$ and the $\chi^{2}$ test with a significance level of $\mathrm{P} \leq 0.01$. Standard deviations were calculated using the averages from the experiments. The statistical analysis for calculating LDs was the trimmed Spearman-Karber analysis (1978). ${ }^{[26]}$

\section{RESULTS AND DISCUSSION}

Topical treatment on $O$. fasciatus using khellin resulted in $40-50 \%(P<0.001)$ nymph mortality at 10 and $100 \mu \mathrm{g} / \mathrm{nymph}$, and 50-80\% $(P<0.001)$ adult mortality (1, 10 and $100 \mu \mathrm{g} / \mathrm{nymph}$ ) [Table $1 \mathrm{~A}$ ], as well as a $22 \%$ reduction in adult longevity (100 $\mu \mathrm{g} / \mathrm{nymph})$ [Table $1 \mathrm{~A}]$. The control groups did not show significant mortality, and the result was that $31-55 \%$ of adults lived for up to 35 days after the treatment [Table 1A]. The time of $O$. fasciatus molting was not significantly different in the khellin treatments. The insects treated with khellin presented egg-laying of 85 to 100 eggs $(P<0.01)$ at 10 and $100 \mu \mathrm{g} / \mathrm{nymphs}$, while the controls presented 118 to 200 eggs. The treated group showed $90 \%$ to $100 \%$ inhibition of egg hatching from normal oviposition at concentrations of 10 and $100 \mu \mathrm{g} /$ nymphs, respectively [Table 1B].

A. aegypti larvae (L3) treated with khellin showed a shorter larval stage period (1-5 days $v s$. 3-9 and 4-7 days for the controls) $(P<0.001)$ and a shorter L3-adult stage period (2-10 days $v s .4-11$ and 5-11 days for the controls), at $50 \mu \mathrm{g} / \mathrm{mL}$ [Table 2A]. These time intervals from larval stage to pupae stage did not show any significant differences in relation to the time intervals for the control groups [Table 2A]. Nevertheless, A. aegypti larvae (L3) treated with khellin solutions showed viability of $53 \%$ $(50 \mu \mathrm{g} / \mathrm{mL})(P<0.1)$ and $70 \%(10 \mu \mathrm{g} / \mathrm{mL})$ in the larval stage, but $100 \%$ emergence (pupae to adults) [Table $2 \mathrm{~B}$ ]. The khellin treatment showed 50\% larval toxicity at $50 \mu \mathrm{g} / \mathrm{mL}(P<0.1)$ [Table $2 \mathrm{C}$ ] and LC50 of $50 \mu \mathrm{g} / \mathrm{mL}$.

\begin{tabular}{|c|c|c|c|c|c|c|c|}
\hline \multirow{2}{*}{$\begin{array}{l}\text { Treatment } \\
\text { A }\end{array}$} & \multicolumn{2}{|c|}{ Period days } & \multicolumn{2}{|c|}{ Ecdysis } & \multirow{2}{*}{$\frac{\text { Nymph mortality }}{\%}$} & \multirow{2}{*}{$\frac{\text { Adults mortality }}{\%}$} & \multirow{2}{*}{$\frac{\text { Adults longevity (35 days) }}{\%}$} \\
\hline & $\mathrm{X} \pm \mathrm{SD}$ & $\mathrm{VI}$ & $\mathrm{X} \pm \mathrm{SD}$ & $\%$ & & & \\
\hline Control & $10.3 \pm 5.9 \mathrm{a}$ & $2-17$ & $20 \pm 1.0 \mathrm{a}$ & 100 & 0 & 20 & 55 \\
\hline acetone & $2.6 \pm 1.9 b^{* * *}$ & $1-7$ & $13 \pm 1.0 \mathrm{~b}$ & 100 & 35 & 38 & 31 \\
\hline $1 \mu \mathrm{g}$ & $4.1 \pm 2.4 \mathrm{~b}$ & $3-10$ & $16 \pm 2,0 \mathrm{~b}$ & 100 & 20 & $50 * * *$ & 30 \\
\hline $10 \mu \mathrm{g}$ & $5 \pm 2.9 \mathrm{~b}$ & $3-10$ & $11 \pm 1.0 \mathrm{~b}$ & 92 & 40 & $55^{* * *}$ & 31 \\
\hline $100 \mu \mathrm{g}$ & $5.1 \pm 3.6 b$ & $3-17$ & $10 \pm 0.5 b$ & 100 & $50 * * *$ & $80^{* * *}$ & $9^{* * *}$ \\
\hline B & \multicolumn{3}{|c|}{ eggs/female } & \multicolumn{2}{|r|}{ eggs $X \pm S D$} & \multicolumn{2}{|r|}{ Eggs viability (F2) \% } \\
\hline Control & \multicolumn{3}{|c|}{50} & \multicolumn{2}{|r|}{$200 \pm 2.0 a$} & \multicolumn{2}{|r|}{55} \\
\hline acetone & \multicolumn{3}{|c|}{19.7} & \multicolumn{2}{|r|}{$118 \pm 12 b * *$} & \multicolumn{2}{|r|}{66} \\
\hline $1 \mu \mathrm{g}$ & \multicolumn{3}{|c|}{50} & \multicolumn{2}{|r|}{$150 \pm 2.0 \mathrm{~b}$} & \multicolumn{2}{|r|}{43} \\
\hline $10 \mu \mathrm{g}$ & \multicolumn{3}{|c|}{17} & \multicolumn{2}{|r|}{$85 \pm 5.0 c^{*}$} & \multicolumn{2}{|r|}{0} \\
\hline $100 \mu \mathrm{g}$ & \multicolumn{3}{|c|}{25} & \multicolumn{2}{|r|}{$100 \pm 30 b$} & \multicolumn{2}{|r|}{10} \\
\hline
\end{tabular}

Treatment with khellin furanocromone on $O$. fasciatus at 1, 10, $100 \mu \mathrm{g} /$ nymph concentrations. Mean values and standard deviation $(\mathrm{X} \pm \mathrm{SD})$, percentage $(\%)$ and range of variation (VI). Experiment conducted with 20 fifth instar nymphs of each group in triplicate and three repetitions. Values followed by the same letter $(\mathrm{a}=\mathrm{a}, \mathrm{b}=\mathrm{b}, \mathrm{c}=\mathrm{c})$ have no significant differences $\mathrm{P}>0.05$ for the Tukey test. Significance levels are represented by as $* * * \mathrm{P}<0.001,{ }^{*} \mathrm{P}=<0.01,{ }^{*} \mathrm{P}<0.1$ vs. control acetone (testimony). 


\begin{tabular}{|c|c|c|c|c|c|c|c|c|}
\hline \multirow{2}{*}{$\begin{array}{l}\text { Treatment } \\
\text { A }\end{array}$} & \multicolumn{4}{|c|}{ Larval (days) } & \multicolumn{2}{|c|}{ Pupal (days) } & \multicolumn{2}{|c|}{ L3 - adult (days) } \\
\hline & \multicolumn{2}{|c|}{$X \pm S D$} & \multicolumn{2}{|c|}{ VI } & $X \pm S D$ & $\mathrm{VI}$ & $X \pm S D$ & $\mathrm{VI}$ \\
\hline Control & \multicolumn{2}{|c|}{$5.9 \pm 1.3 \mathrm{a}$} & \multicolumn{2}{|c|}{$(3-9)$} & $2.3 \pm 0.9 a$ & $(1-4)$ & $9 \pm 1 a$ & $(4-11)$ \\
\hline Acetone & \multicolumn{2}{|c|}{$5.4 \pm 0.8 a$} & \multicolumn{2}{|c|}{$(4-7)$} & $2.6 \pm 0.9 a$ & $(1-4)$ & $9 \pm 1 a$ & $(5-11)$ \\
\hline $10 \mu \mathrm{g} / \mathrm{mL}$ & \multicolumn{2}{|c|}{$4.3 \pm 2 c^{* *}$} & \multicolumn{2}{|c|}{$(1-8)$} & $3 \pm 0.7 \mathrm{a}$ & $(2-4)$ & $7 \pm 4 c^{*}$ & $(3-11)$ \\
\hline $50 \mu \mathrm{g} / \mathrm{mL}$ & \multicolumn{2}{|c|}{$2.7 \pm 1.6 b^{* * *}$} & \multicolumn{2}{|c|}{ (1-5) } & $3 \pm 0.8 \mathrm{a}$ & $(1-4)$ & $4.9 \pm 3.6 b^{* * *}$ & $(2-10)$ \\
\hline \multirow[t]{2}{*}{$B$} & \multicolumn{2}{|c|}{ L3-L4 } & \multicolumn{2}{|c|}{ L4-Pupae } & \multicolumn{2}{|c|}{ Pupae } & \multicolumn{2}{|c|}{ L3 - adult } \\
\hline & $X \pm S D$ & $\%$ & $X \pm S D$ & $\%$ & $X \pm S D$ & $\%$ & $X \pm S D$ & $\%$ \\
\hline Control & $10 \pm 0 \mathrm{a}$ & 100 & $10 \pm 0 a$ & 100 & $10 \pm 0 \mathrm{a}$ & 100 & $10 \pm 0 a$ & 100 \\
\hline Acetone & $10 \pm 0 a$ & 100 & $10 \pm 0 a$ & 100 & $10 \pm 0 \mathrm{a}$ & 100 & $10 \pm 0 a$ & 100 \\
\hline $10 \mu \mathrm{g} / \mathrm{mL}$ & $10 \pm 0 a$ & 70 & $7 \pm 1.7 a$ & 100 & $7 \pm 1.7 \mathrm{a}$ & 100 & $7 \pm 1.7 a$ & 70 \\
\hline $50 \mu \mathrm{g} / \mathrm{mL}$ & $10 \pm 0 a$ & 53 & $5 \pm 3 b^{*}$ & 93,7 & $5 \pm 2.6 b^{*}$ & 100 & $5 \pm 2.6 b^{*}$ & 50 \\
\hline \multirow[t]{2}{*}{$\mathrm{C}$} & \multicolumn{3}{|c|}{ L3 } & \multicolumn{3}{|c|}{ L4 } & \multirow{2}{*}{\multicolumn{2}{|c|}{ Pupae }} \\
\hline & $X \pm S D$ & VI & $\%$ & $X \pm S D$ & $\mathrm{VI}$ & $\%$ & & \\
\hline Control & 0 & 0 & 0 & 0 & 0 & 0 & 0 & \\
\hline Acetone & 0 & 0 & 0 & 0 & 0 & 0 & 0 & \\
\hline $10 \mu \mathrm{g} / \mathrm{mL}$ & $3 \pm 1,7 a$ & $(3-3)$ & 30 & 0 & 0 & 0 & 0 & \\
\hline $50 \mu \mathrm{g} / \mathrm{mL}$ & $4,6 \pm 3 b^{*}$ & $(1-1)$ & 46.6 & $0.3 \pm 0.5$ & $(0-3)$ & 3.3 & 0 & \\
\hline
\end{tabular}

Experiments with 10 larvae (L3) of A. aegypti, for each test group and control, in triplicate, with three repetitions ( $\mathrm{n}=30$ ). Mean and standard deviation (X \pm SD). Range of Variation (VI). Values followed by the same letter $(\mathrm{a}=\mathrm{a}, \mathrm{b}=\mathrm{b}, \mathrm{c}=\mathrm{c})$ have no significant differences. Levels of significance by the Tukey test, represented as $* * * \mathrm{P}<0.001$, $* * \mathrm{P}=$ $<0.01, * \mathrm{P}<0.1$ vs. acetone control (testimony)

Mortality was not observed in the acetone control solution (without khellin) and untreated solution (control) [Table 2C].

Based on these findings, khellin appears to have potential as a substance acting against the milkweed bug and dengue vector. The present results showed $50 \%$ toxicity in relation to $O$. fasciatus, and this mortality rate was not correlated with any reduced in the molting cycle. However, the same substance has been found to cause $99.5 \%$ inhibition of larval growth on Spodoptera littoralis. ${ }^{[27]}$ In relation to pests of stored products, coumarin has shown insecticide activity at LD50 of $2.72-39.71 \mathrm{mg} / \mathrm{g}$. ${ }^{[28]}$ The toxicity of khellin was demonstrated by the fact that only $10 \%$ of the milkweed bugs' eggs hatched. The toxic effect of khellin on the larvae of A. aegypti corroborates the toxic effect on $O$. fasciatus produced by treatment with coumarin. Coumarin (3, 6, 8-tribromo-7hydroxy-4-methyl-chromen-2-one) has been found to be a potent larvicidal agent against L4 larvae of $A$. aegypti at LC50 $=2.23 \mathrm{ppm}$. It has been shown to produce $100 \%$ larval mortality at $25 \mathrm{ppm}$ against these mosquitoes. ${ }^{[29]}$ The same activity has been demonstrated by 4-hydroxycoumarin derivatives, with a strong larvicidal effect at LC50 values of $8.23 \mathrm{ppm}$ against $A$. aegypti. ${ }^{[30]}$

\section{CONCLUSION}

Further experiments should be conducted in order to demonstrate the possible effects of khellin on the internal and external morphology of mosquitoes and phytophagous insects. Our findings are consonant with the hypothesis that this substance may be used for insect control, thereby reducing insect vector and pest populations.

\section{ACKNOWLEDGEMENT}

This research was supported by grants from Fundação de Amparo a Pesquisa do Estado do Rio de Janeiro (FAPERJ), Fundação Nacional de Desenvolvimento do Ensino Superior Particular (FUNADESP) and Fundação para o Desenvolvimento Científico e Tecnológico (FIOTEC); with thanks to Dr. Nildimar Honorio Rocha (IOC/FIOCRUZ) for the eggs of A. aegypti. Financial support was also received from FCT-Portugal (CEQUIMED-PEst-OE/SAU/UI4040/2011) FEDER, POCI, PTDC/SAU-FCF/100930/2008-COMPETE, QREN, EU/FEDER, University of Porto.

\section{REFERENCES}

1. Siddiqui BS, Gulzar T, Mahmood A, Begum S, Khan B, Afshan F. New insecticidal amides from petroleum ether extract of dried Piper nigrum L. whole fruits. Chem Pharm Bull (Tokyo) 2004;52:1349-52.

2. Silva IG, Guimarães VP, Lima CG, Silva HH, Elias CN, Mady CM, et al. Efeito larvicida e toxicológico do extrato bruto etanólico da casca do caule de Magonia pubescens sobre Aedes aegypti (Diptera: Culicidae) em criadouros artificiais. RPT 2003;32:73-86.

3. Morandi Filho WJ, Botton M, Grützmacher AD, Giolo FP, Manzoni CG. Ação de produtos naturais sobre a sobrevivência de Argyrotaenia sphaleropa (Meyrick) (Lepidoptera: Tortricidae) e seletividade de inseticidasutilizados naproduçãoorgânica de videira sobre Trichogramma pretiosumRiley (Hymenoptera: Trichogrammatidae). Ciencia Rural Santa Maria 2006;36:1072-8.

4. World Health Organization. Dengue Hemorrhagic Fever: Diagnosis, Treatment, Prevention and Control. Geneva, Switzerland: WHO; 2009.

5. Cabral MM, Barbosa-Filho JM, Maia GL, Chaves MC, Braga MV, De Souza $\mathrm{W}$, et al. Neolignans from plants in northeastern Brazil (Lauraceae) with activity against Trypanosomacruzi. Exp Parasitol 2010;124:319-24.

6. Günaydin K, Beyazit N. The chemical investigations on the ripe fruits of Ammivisnaga (Lam.) Lamarck growing in turkey. Nat Prod Res 2004;18:169-75. 
7. Bencheraiet R, Kherrab H, Kabouche A, Kabouche Z. Jay M. Flavonols and antioxidant activity of Ammi visnaga L. (Apiaceae). Rec Nat Prod 2011;5:52-5.

8. Khalfallah A, Labed A, Semra Z, Ai Kaki B, Kabouche A, Touzani R, et al. Antibacterial activity and chemical composition of essential oil of Ammi visnaga L. (Apiaceae). from Constantine, Algeria. Int J Med Aromat Plant 2011;1:302-5.

9. Cordero CP, Gómez-González S, León-Acosta CJ, Morantes-Medina SJ, Aristizabal FA. Cytotoxic activity of five compounds isolated from Colombian plants. Fitoterapia 2004;75:225-7.

10. Whitton ME, Ashcroft DM, González U. Therapeutic interventions for vitiligo. J Am Acad Dermatol 2008;59:713-7.

11. De Leeuw J, Assen YJ, van der Beek N, Bjerring P, Martino Neumann HA. Treatment of vitiligo with khellin liposomes, ultraviolet light and blister roof transplantation. J Eur Acad Dermatol Venereol 2011;25:74-81.

12. Paula AR, Carolino AT, Paula CO, Samuels RI. The combination of the entomopathogenic fungus Metarhizium anisopliae with the insecticide Imidacloprid increases virulence against the dengue vector Aedes aegypti (Diptera: Culicidae). Parasit Vectors 2011;4:8.

13. Nelson MJ. Aedes aegypti: Biologia e ecologia. Washington DC: Pan American Health Organization; 1986.

14. Consoli RA, Oliveira RL. Principais Mosquitos de Importância Sanitária do Brasil. Rio de Janeiro: Editora Fiocruz; 1994. p. 228.

15. Teixeira Mda G, Costa Mda CN, Barreto ML, Mota E. Dengue and dengue hemorrhagic fever epidemics in Brazil: What research is needed based on trends, surveillance, and control experiences. Cad Saude Publica 2005;21:1307-15.

16. Montella IR, Martins AJ, Viana-Medeiros PF, Lima JB, Braga IA, Valle D. Insecticide resistance mechanisms of Brazilian Aedes aegypti populations from 2001 to 2004. Am J Trop Med Hyg 2007;77:467-77.

17. Da-Cunha MP, Lima JB, Brogdon WG, Moya GE, Valle D. Monitoring of resistance to the pyrethroid cypermethrin in Brazilian Aedes aegypti (Diptera: Culicidae) populations collected between 2001 and 2003. Mem Inst Oswaldo Cruz 2005;100:441-4.

18. Feir D. Oncopeltus fasciatus: A research animal. Annu Rev Entomol 1974;19:81-96.

19. Andre F. Notes on the biology of Oncopeltus fasciatus (Dallas). Iowa State Coll J Sci 1934;:73-87.

20. Best RL, Apud Ventura UM, Panizzi. AR. Megalotomus parvus West. (Hemiptera: Alydidae): an insect for research and teaching purposes.
An Soc Entomol Bras 1997; 26:579-81.

21. Costa Lima, A. Insetos do Brasil: Hemiptera. Escola de Agronomia, Série Didática Número 3. Rio de Janeiro: Escola de Agronomia; 1940. p. 97.

22. Narciso, JO, Souza MA, Carvalho MG, Gomes MS, Genestra M, Cabral MM. Flavonoids inhibited NADPH consumption and ecdysis processes in Oncopeltus fasciatus.J Nat Pharm 2011;2:133-7.

23. Cabral MM, Alencar JA, Guimarães AE, Kato MJ. Larvicidal Activity of Grandisin against Aedes aegypti. J Am Mosq Control Assoc 2009;25:103-5.

24. Narciso JO. Atividade larvicida de neolignana isolada de Ocotea cymbarum sobre Aedes aegypti L. (Diptera: Culicidae). Monografia de Especialização em Entomologia Médica. Rio de Janeiro, Brasil: Instituto Oswaldo Cruz; 2009.

25. Motulsky HJ. Analyzing data Graph Pad prism. San Diego, CA: Graph Pad Software Inc.; 1999.

26. Hamilton MA, Russo RC, Thurston RV. Trimmed sperman-karber method for estimating median lethal concentration in toxicity bioassays. Environ Sci Technol 1977;11:714-9.

27. Sayed HM, Mohamed MH, Farag SF, Mohamed GA, Proksch P. A new steroid glycoside and furachromones from Cyperus rotundus $\mathrm{L}$. Nat Prod Res 2004;21:343-50.

28. Moreira MD, Picanço MC, Barbosa LC, Guedes RN, Campos MR, Silva GA, et al. Plant compounds insecticide activity against Coleoptera pests of stored products. Pesqui Agropecu Bras Brasília 2007;42:909-15.

29. Deshmukh M, Pawar P, Joseph M, Phalgune U, Kashalkar R, Deshpande NR. Efficacy of 4-Methyl- 7 Hydroxy coumarin derivates against vectors Aedes aegypti and Culex quinquefasciatus. Indian J Exp Biol 2008;46:788-92.

30. Jung JC, Moon HI. Larvicidal activity of 4-hydroxycoumarin derivatives against Aedes aegypti. Pharm Biol 2011;49:190-3.

Cite this article as: Maleck M, Carvalho dos Santos FC, Serdeiro MT, Guimarães AÉ, Ferreira B, Gunaydin K, et al. Khellin: A furanochromone with toxicity against Oncopeltus fasciatus (Hemiptera) and Aedes aegypti (Diptera). J Nat Pharm 2013;4:32-6.

Source of Support: This research was supported by grants from Fundação de Amparo a Pesquisa do Estado do Rio de Janeiro (FAPERJ), Fundação Nacional de Desenvolvimento do Ensino Superior Particular (FUNADESP), Fundação para o Desenvolvimento Científico e Tecnológico (FIOTEC). and FCT-Portugal (CEQUIMED-PEst-OE/SAU/UI4040/2011) FEDER, POCI, PTDC/SAU-FCF/100930/2008-COMPETE, QREN, EU/FEDER, University of Porto. Conflict of Interest: None declared. 